\title{
Bioaccumulation of Heavy Metals in Selected Organs of Black Locust (Robinia pseudoacacia) and their Potential Use as Air Contamination Bioindicators
}

\author{
Bernard Palowski ${ }^{1}$, Elżbieta Małkowska ${ }^{1}$, Renata Kurtyka ${ }^{2}$, \\ Joanna Szymanowska-Pułka ${ }^{3}$, Ewa Gucwa-Przepióra ${ }^{4}$, Lukasz Małkowski ${ }^{4}$, \\ Andrzej Woźnica ${ }^{5}$, Eugeniusz Małkowski ${ }^{2 *}$ \\ ${ }^{1}$ Department of Ecology, Faculty of Biology and Environmental Protection, University of Silesia, \\ Bankowa 12, 40-032 Katowice, Poland \\ ${ }^{2}$ Department of Plant Physiology, Faculty of Biology and Environmental Protection, University of Silesia, \\ Jagiellońska 28, 40-032 Katowice, Poland \\ ${ }^{3}$ Department of Biophysics and Morphogenesis of Plants, Faculty of Biology and Environmental Protection, \\ University of Silesia, Jagiellońska 28, 40-032 Katowice, Poland \\ ${ }^{4}$ Department of Botany and Nature Protection, Faculty of Biology and Environmental Protection, University of Silesia, \\ Jagiellońska 28, 40-032 Katowice, Poland \\ ${ }^{5}$ Department of Biochemistry, Faculty of Biology and Environmental Protection, University of Silesia, \\ Jagiellońska 28, 40-032 Katowice, Poland
}

Received: 12 September 2015

Accepted: 12 April 2016

\begin{abstract}
We analyzed concentrations of $\mathrm{Cd}, \mathrm{Cu}, \mathrm{Fe}, \mathrm{Pb}$, and $\mathrm{Zn}$ in bark, leaves, young shoots, pericarp, and seeds of Robinia pseudoacacia from several sites (three industrial cities and two rural villages) in southern Poland. The objective of the study was to determine the possible usefulness of various organs and tissues of this species for biomonitoring. The analyses showed that bark and leaves are organs that may serve as good bioindicators. The lowest concentrations of $\mathrm{Cd}, \mathrm{Pb}$, and $\mathrm{Zn}$ were found in one of the industrial cities in the area. On the other hand, the concentrations of $\mathrm{Cd}, \mathrm{Pb}$, and $\mathrm{Zn}$ were similar in the rural areas when compared to the concentrations observed in the cities. The high level of metal contamination of air in rural areas may be a result of the long-range transport of emissions. Also, the use of bark and leaves of R. pseudoacacia enables us to estimate the level of contamination by $\mathrm{Fe}$ and $\mathrm{Cu}$ of areas in the vicinity of railway tracks. On the basis of the data presented in this paper and the data from references, a conclusion can be drawn that the bark and leaves of $R$. pseudoacacia are good bioindicators of metal contamination of air in towns and
\end{abstract}

*e-mail: eugeniusz.malkowski@us.edu.pl 
cities with different traffic intensities and within the surroundings of industrial plants and railway tracks.

$R$. pseudoacacia was also used for the first time to assess the long-range transport of emissions.

Keywords: biomonitoring, Robinia pseudoacacia, plant organs, traffic emissions, long-range transport

\section{Introduction}

Since the beginning of the industrial revolution contamination of the environment by toxic metals has increased dramatically worldwide. Ferrous and nonferrous smelting and mining, road traffic, combustion of fossil fuels, and waste incineration are major contributory factors in the rise of $\mathrm{Cd}, \mathrm{Cu}, \mathrm{Pb}, \mathrm{Zn}$, and $\mathrm{Fe}$ levels in soil, water, and air. All those metals may have a negative effect on plants, animals, and human beings [1]. Thus monitoring becomes a necessary tool for maintaining the concentrations of metals in the biosphere at a safe level.

Biomonitoring is a technique based on analysis of organisms or biomaterials to obtain data on environmental contamination, which is also a relatively cost-effective method and can be successfully applied worldwide [2]. This technique seems to be particularly useful in air monitoring. So far the vast majority of measurements of metal concentration in the atmosphere have been carried out using lichens and mosses [3-14]. However, in polluted areas higher plants seem to be more suitable as ecological indicators of air contamination, since lichens and mosses are often missing from such environments [15-16].

Various species of herbaceous plants [17-23] and trees $[16,24-30]$ have been used to monitor concentrations of metals in the air. In urban environments, however, trees seem to be more suitable as ecological indicators because crowns and bark are very efficient at trapping atmospheric particles [16, 31-33]. So far most studies have been performed on coniferous tree species from the genus Pinus, e.g. P. sylvestris [34-38], P. halepensis [15], or P. nigra [39]. Investigations also have been carried out on deciduous trees, among which Aesculus hippocastanum [40-42], Salix spp. [43-45], Populus spp. [39-40, 43], Quercus spp. [24-25, 39], and Fraxinus spp. [40, 46-47] have mostly been chosen.

When compared to other deciduous or coniferous trees there is still a dearth of data on the use of Robinia pseudoacacia in the determination of metal levels in the air, although it has various positive features as a bioindicator. Black locust (Robinia pseudoacacia L.) is a deciduous tree species native to North America [48], nevertheless, it occurs in Europe, Asia, Australia, Africa, and also in parts of South America [32, 49-51], where it is planted for ornamental purposes and to stabilize dry soil as it can survive in a wide temperature range and grows in almost any type of soil [ 49 and literature therein, 52]. This species is mainly planted along roadsides in both urban and rural areas as it is resistant to environmental pollution [32, 5354]. Moreover, sampling, identification, and cultivation of R. pseudoacacia is easy and inexpensive [32, 49].

Few papers on $R$. pseudoacacia as a bioindicator have been published so far. Most of them report on metal emissions in Turkey and concern industrial, urban, and rural areas [39-40, 49, 55-57]. As far as the authors are concerned there are four papers that present data from other parts of the world, namely Poland [32], Macedonia [58], Serbia [59], and Iran [60]. All these articles present results of studies on $R$. pseudoacacia as a bioindicator of direct industrial and/or road traffic emissions. To the authors' knowledge there have been no studies on how this tree species could be used as an indicator of long-range atmospheric transport of metal contaminants.

Various tree parts such as leaves, bark, and shoots as well as tree rings are used for bioindication purposes. Predominantly leaves have been examined in $R$. pseudoacacia [32, 39-40, 43, 49, 55-56, 58-60], whereas concentrations of metals in bark [32], shoots [57, 5960], or flowers [58] have seldom been investigated. The suitability of other organs or tissues of $R$. pseudoacacia for bioindication purposes has not been examined so far. However, investigations have shown that metals can be taken up by leaves and translocated to different plant organs. For example, foliar spray of $\mathrm{Zn}, \mathrm{Cu}$, and $\mathrm{Fe}$ is commonly used as a form of fertilization and results in the distribution of metals to different plant parts [6162]. Moreover, it was found that cadmium applied as a solution on the leaves of various wheat species was taken up and translocated to the remainder of shoots as well as to the roots [63]. Similar results were obtained with dicotyledonous plants. The uptake of $\mathrm{Cd}$ by the tips of leaves and the transport of the metal to petioles and stipules were observed in Pisum sativum [64]. Moreover, experiments conducted on this plant species in a filtered air growth cabinet showed that atmospheric $\mathrm{Pb}$ and $\mathrm{Cd}$ can contribute to metal concentration in pods $(\mathrm{Cd}, \mathrm{Pb})$ and peas $(\mathrm{Pb})$ [65 and literature therein].

The objectives of the present study were to assess $R$. pseudoacacia as a potential bioindicator of the contamination of air with metals $(\mathrm{Cd}, \mathrm{Cu}, \mathrm{Fe}, \mathrm{Pb}, \mathrm{Zn})$ resulting from direct industrial and road traffic emissions as well as long-range atmospheric transport. Also, the usefulness of selected organs and tissues for bioindication was determined. For this reason we examined metal accumulation $(\mathrm{Cd}, \mathrm{Cu}, \mathrm{Fe}, \mathrm{Pb}, \mathrm{Zn})$ in bark, leaves, young shoots, pericarps, and seeds of $R$. pseudoacacia.

\section{Materials and Methods}

\section{Study Area}

The present study was carried out in two areas: the industrial area of the Upper Silesian Industrial Region (USIR) and a rural area in the vicinity of Kraków - both of which are in southern Poland (Fig. 1). 


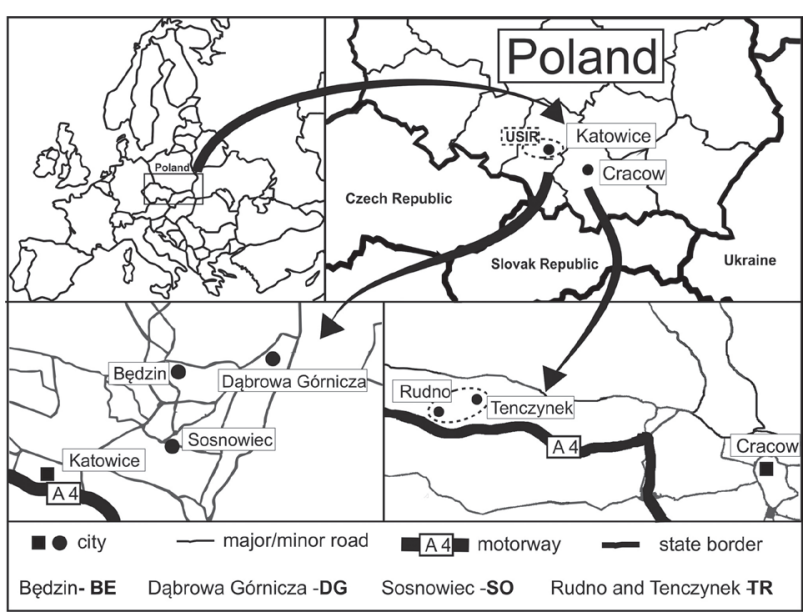

Fig. 1. Location of the study area.

Field sampling was conducted in the cities of Będzin, Dąbrowa Górnicza, and Sosnowiec in the USIR - a region that has been the site of intensive coal mining as well as $\mathrm{Zn} / \mathrm{Pb}$ and $\mathrm{Fe}$ smelting since the $19^{\text {th }}$ century. Power plants, smelters, coal mines, and chemical plants are situated within the cities. Moreover, chemical and food industries, coke-oven batteries as well as machine and electrical engineering also account for emissions of metal contaminants in the region [66].

Rudno and Tenczynek were the second sampling site. They are villages situated close to Kraków, one of the largest Polish cities. Rudno is located in the Tenczynek Natural Landscape Park, whereas Tenczynek is situated in the park's vicinity and both villages are holiday resorts. Although Tenczynek and Rudno are located in a non-industrial area, they are surrounded by a number of industrial plants, e.g., the Alwernia chemical plant $(8 \mathrm{~km})$, Trzebinia oil refinery $(11 \mathrm{~km})$, the Boleslaw Mine and Metalurgical Plant in Bukowno (lead and zinc smelter, 19 $\mathrm{km})$, the Jaworzno III power plant $(21 \mathrm{~km})$, and Dwory Chemical Company $(22 \mathrm{~km})$. In addition, the A4 motorway runs south of the site.

The USIR was chosen as a sampling site because it is an area with direct industrial and road traffic pollution emissions, whereas Tenczynek and Rudno were chosen as villages exposed to long-range atmospheric transport of contaminants.

\section{Sample Collection}

Samples were collected in the USIR in September 2007 and 2008 from Będzin (BD), Dąbrowa Górnicza (DG), and Sosnowiec (SO), and from the villages Tenczynek and Rudno (both TR). Collection of samples was carried out in September in order to determine the concentration of metals that had been accumulating for the whole vegetative period. Samples were taken in each city (BD, DG, SO) at five sampling sites (e.g., BD1, $\mathrm{BD} 2, \mathrm{BD} 3, \mathrm{BD} 4, \mathrm{BD} 5)$ and in both villages (TR) at four sampling sites (TR1, TR2, TR3, TR4) for a total of 19 sites altogether (Table 1). Each sampling site consisted of a clump of at least five trees. In each case black locust (Robinia pseudoacacia L.) seed pods were taken from all trees in the clump and subsequently divided into seeds (S), pericarps (P), bark (B), leaves (L), and young shoots (SH).

The tree trunks were cleaned with a brush at a height of $1.3 \mathrm{~m}$ above the ground in order to remove the deposited dust particles. Then bark samples of 2-3 mm thickness were collected. Four to five young greenish shoots and 10-15 bunches of pods were collected up to a height of $3.5 \mathrm{~m}$ from all sides of the crown. Leaves $(500-800 \mathrm{~g}$ of fresh weight) were taken up to $3.5 \mathrm{~m}$ from all sides of the crown as well as from its centre.

\section{Sample Preparation and Analysis}

In the laboratory the collected plant material was rinsed several times with tap water and then with distilled water in order to remove current contaminants as per [18, $42,60]$. The material was subsequently air-dried and pods were divided into seeds and pericarps. The air-dried samples were ground in a mill. The plant tissue was then dried in an oven at $105^{\circ} \mathrm{C}$. In order to analyze the concentration of metals for each sampling site three subsamples were prepared from the dried plant tissue. The subsamples were subsequently dry-ashed at $460^{\circ} \mathrm{C}$ for $24 \mathrm{~h}$. The ash was dissolved in $10 \% \mathrm{HNO}_{3}$ and filtered (filter paper with pore diameter of 3-5 $\mu \mathrm{m}$ ) [67]. In the resulting solution the concentrations of $\mathrm{Cd}, \mathrm{Cu}, \mathrm{Fe}, \mathrm{Pb}$, and $\mathrm{Zn}$ were determined using of flame atomic absorption spectrophotometry (Unicam 939 Solar). The total number of analyzed subsamples of all tree organs and tissues from all sampling sites amounted to 285 .

Table 1. Categories of sampling site locations distinguished on the basis of metal emission sources (industry, traffic, and railway).

\begin{tabular}{|c|c|c|c|c|c|}
\hline \multirow{2}{*}{\multicolumn{2}{|c|}{$\begin{array}{l}\text { Categories of sampling } \\
\text { site locations }\end{array}$}} & \multicolumn{4}{|c|}{ Sampling sites } \\
\hline & & $\begin{array}{c}\text { Będzin } \\
(\mathrm{BD})\end{array}$ & $\begin{array}{c}\text { Dąbrowa Górnicza } \\
\text { (DG) }\end{array}$ & $\begin{array}{l}\text { Sosnowiec } \\
\text { (SO) }\end{array}$ & $\begin{array}{l}\text { Tenczynek and } \\
\text { Rudno (TR) }\end{array}$ \\
\hline Industry and heavy traffic & $\mathrm{IH}$ & BD3 & DG3, DG4 & $\mathrm{SO} 1, \mathrm{SO} 2, \mathrm{SO} 4$ & \\
\hline Railway & RW & BD2 & DG2 & SO5 & TR1 \\
\hline Industry and low traffic & IL & $\mathrm{BD} 1, \mathrm{BD} 4, \mathrm{BD} 5$ & DG1, DG5 & $\mathrm{SO} 3$ & \\
\hline $\begin{array}{c}\text { Long-range atmospheric } \\
\text { transport }\end{array}$ & LR & & & & TR2, TR3, TR4 \\
\hline
\end{tabular}


Table 2. Metal concentrations ( $\mathrm{mg} \mathrm{kg}^{-1}$ ) in organs and tissues (bark, leaves, seeds, pericarps, shoots) of Robinia pseudoacacia according to the categories of sampling site locations (IH, RW, IL, LR).

\begin{tabular}{|c|c|c|c|c|c|}
\hline \multirow{2}{*}{ Element } & \multirow{2}{*}{$\begin{array}{c}\text { Organ } \\
\text { or tissue }\end{array}$} & \multicolumn{4}{|c|}{ Categories of sampling site locations } \\
\hline & & $\mathrm{IH}$ & RW & IL & LR \\
\hline \multirow{5}{*}{$\mathrm{Cd}$} & bark & $2.44 \pm 0.17 \quad(2.52) \mathrm{a}$ & $2.19 \pm 0.12 \quad(2.27) \mathrm{a}$ & $2.21 \pm 0.10 \quad(2.20) \mathrm{a}$ & $2.63 \pm 0.14 .(2.74)$ \\
\hline & leaves & $2.20 \pm 0.07 \quad(2.26)$ a. $A B$ & $1.95 \pm 0.16 \quad(1.94)$ ab.AB & $1.74 \pm 0.13 \quad$ (1.83) ab.B & $2.40 \pm 0.19 \quad(2.74) \mathrm{A}$ \\
\hline & seeds & $1.21 \pm 0.09$ (1.28) b.B & $1.54 \pm 0.16 \quad(1.49)$ ab.AB & $1.45 \pm 0.13 \quad(1.28)$ bc. $\mathrm{AB}$ & $1.89 \pm 0.21 \quad(1.67) \mathrm{A}$ \\
\hline & pericarps & $1.39 \pm 0.13 \quad(1.28) b$ & $1.31 \pm 0.16 \quad(1.06) b$ & $1.25 \pm 0.07 \quad(1.28) \mathrm{c}$ & $2.08 \pm 0.28(2.50)$ \\
\hline & shoots & $1.53 \pm 0.10 \quad(1.49) \mathrm{b}$ & $1.79 \pm 0.17 \quad(1.66) \mathrm{ab}$ & $1.41 \pm 0.11 \quad(1.28) b c$ & $1.76 \pm 0.22(1.67)$ \\
\hline \multirow{5}{*}{$\mathrm{Fe}$} & bark & $211.5 \pm 22.07 \quad(207.9)$ a.BC & $558.6 \pm 127.72 \quad(354.9)$ a.AB & $211.2 \pm 33.97$ (151.0) a.C & $600.3 \pm 88.42(496.7)$ a.A \\
\hline & leaves & $59.7 \pm 3.75$ (54.9) b.B & $95.8 \pm 10.71 \quad(85.4)$ ab.A & $58.1 \pm 5.71 \quad(56.3)$ b.B & $53.8 \pm 7.03$ (61.9) bc.AB \\
\hline & seeds & $66.7 \pm 3.62 \quad(63.9)$ b. $A B$ & $72.0 \pm 1.96(85.4)$ b.A & $58.7 \pm 1.19 \quad(58.0)$ b.B & $62.3 \pm 6.01(62.0) \mathrm{ab} . \mathrm{AB}$ \\
\hline & pericarps & $55.9 \pm 1.81(52.4)$ b.A & $61.6 \pm 7.35(57.9)$ b.A & $41.3 \pm 2.96$ (36.8) c.B & $20.3 \pm 7.32$ (8.31) bc.B \\
\hline & shoots & $53.8 \pm 2.18 \quad(52.4)$ b.A & $59.3 \pm 7.67$ (61.1) b.A & $43.5 \pm 2.64$ (41.4) bc. $\mathrm{AB}$ & $6.58 \pm 0.82(8.32)$ c.B \\
\hline \multirow{5}{*}{$\mathrm{Pb}$} & bark & $29.4 \pm 1.98 \quad(29.1)$ a.AB & $22.1 \pm 4.26 \quad(22.1) \mathrm{B}$ & $24.3 \pm 3.04 \quad(25.8)$ a. $A B$ & $34.3 \pm 3.44(36.5)$ a.A \\
\hline & leaves & $20.6 \pm 2.81(18.7) \mathrm{ab}$ & $27.3 \pm 4.21 \quad(31.2)$ & $16.1 \pm 2.03(13.9) \mathrm{ab}$ & $16.6 \pm 4.18(8.33) \mathrm{ab}$ \\
\hline & seeds & $10.8 \pm 1.21 \quad(9.16) b$ & $11.1 \pm 2.13(8.31)$ & $10.3 \pm 1.61(8.31) b c$ & $15.1 \pm 3.72(8.33) b$ \\
\hline & pericarps & $15.0 \pm 1.87$ (14.0) b.AB & $19.8 \pm 3.72(14.0) \mathrm{A}$ & $9.26 \pm 1.78$ (6.24) c.B & $27.1 \pm 6.01$ (33.2) ab.A \\
\hline & shoots & $18.4 \pm 2.24(18.7) b$ & $15.9 \pm 2.58$ & $16.9 \pm 2.16(15.3) \mathrm{ab}$ & $10.2 \pm 1.40(8.32) b$ \\
\hline \multirow{5}{*}{$\mathrm{Cu}$} & bark & $9.98 \pm 0.19(9.65)$ ab.A & $10.7 \pm 0.56$ (11.8) a.A & $9.81 \pm 0.48$ (9.64) a.A & $6.83 \pm 0.62$ (6.83) ab.B \\
\hline & leaves & $6.78 \pm 0.65$ (6.24) c.A & $7.86 \pm 0.36$ (8.30) b.A & $6.77 \pm 0.61$ (8.29) b.A & $3.71 \pm 0.28$ (3.53) c.B \\
\hline & seeds & $10.9 \pm 0.18$ (10.6) a.B & $11.8 \pm 0.38$ (11.6) a.AB & $11.5 \pm 0.26(11.3)$ a.AB & $12.3 \pm 0.33$ (11.9) a.A \\
\hline & pericarps & $5.48 \pm 0.66(4.16) \mathrm{c}$ & $4.79 \pm 0.55(4.16) b$ & $4.47 \pm 0.52(4.16) b$ & $4.28 \pm 0.15$ (4.16) bc \\
\hline & shoots & $7.15 \pm 0.73(8.71) b c$ & $6.67 \pm 0.73(6.65) b$ & $6.97 \pm 0.54(8.31) b$ & $4.77 \pm 0.60$ (4.16) bc \\
\hline \multirow{5}{*}{$\mathrm{Zn}$} & bark & $59.0 \pm 5.53(54.7)$ a. $A$ & $35.8 \pm 4.74$ (41.6) bc. В & $47.0 \pm 4.96(52.0)$ a.AB & $52.0 \pm 5.41(53.1)$ ab.AB \\
\hline & leaves & $50.8 \pm 4.70(50.7) \mathrm{a}$ & $42.8 \pm 4.22(42.5) \mathrm{ab}$ & $37.8 \pm 4.12(35.0) \mathrm{a}$ & $52.4 \pm 5.48(46.8) \mathrm{ab}$ \\
\hline & seeds & $124.9 \pm 35.08(64.5) \mathrm{a}$ & $86.6 \pm 22.55(57.9) \mathrm{a}$ & $86.4 \pm 13.64(65.0) \mathrm{a}$ & $73.6 \pm 9.26(90.2) \mathrm{a}$ \\
\hline & pericarps & $15.4 \pm 1.89 \quad(16.6)$ b.A & $13.8 \pm 2.29$ (11.7) c. $\mathrm{AB}$ & $7.45 \pm 0.64$ (7.98) b.B & $24.8 \pm 1.36$ (23.3) c.A \\
\hline & shoots & $107.2 \pm 34.20(61.2)$ a.A & $43.5 \pm 6.50$ (41.5) ab.AB & $40.3 \pm 5.10(38.0)$ a.AB & $35.4 \pm 5.88$ (27.3) bc.B \\
\hline
\end{tabular}

Values are means \pm SE $(n=7-18)$. Numbers in brackets are medians. Medians followed by the same letter are not significantly different from each other using the Kruskal-Wallis non-parametric analysis of variance and post hoc multiple comparison test $(p<0.05)$

a-d. Medians are significantly different for each metal in columns (among organs).

A-B. Medians are significantly different for each organ in rows (among the categories of sampling site location).

$\mathrm{IH}$ - industry and heavy traffic. RW - railway. IL - industry and low traffic. LR - long-range atmospheric transport.

All elements were determined against standards (BDH Chemicals Ltd, pro analysi quality) and blanks were prepared in $0.5 \mathrm{M}$ nitric acid. Blanks and standards contained the same matrix as the samples. The results were calculated on a dry-weight basis.

\section{Statistical Analysis}

On the basis of metal emission sources (industry, traffic, and railway) four categories of sampling site locations were distinguished: 1) close to industrial plants and heavy traffic (IH), 2) close to the railway track (RW), 3) close to industrial plants and low traffic (IL), and 4) far from industry and traffic but exposed to long-range atmospheric transport (LR). Each of the 19 sampling sites was assigned to one of the location categories as shown in Table 1.

We conducted normality tests (chi square or Kolmogorov-Smirnov with the Lilliefors correction) of the measurements of five metal concentrations $(\mathrm{Cd}, \mathrm{Cu}, \mathrm{Fe}, \mathrm{Pb}$, and $\mathrm{Zn})$ in particular plant organs $(\mathrm{B}, \mathrm{L}, \mathrm{S}, \mathrm{P}, \mathrm{SH})$. The 
tests showed that the distribution of most of the variables was far from normal, thus a non-parametric Kruskal-Wallis ANOVA test was run, and post hoc multiple comparison tests (when necessary) were applied to detect significantly different levels of concentrations of particular metals in plant organs and tissues. In other cases a parametric ANOVA test was applied. Correlations between metal concentrations as well as between plant organs were tested through Spearman's $\rho$ coefficient. Cluster analysis using average linkage between groups and Pearson's correlation as a measure interval was applied [68] in order to compare element concentrations in organs and tissues. Statistical analysis was performed using Statistica version 9.0 software (StatSoft Inc, Tulsa, OK, USA).

\section{Results}

\section{Effects of Sampling Site Locations \\ on Metal Concentrations in Organs and Tissues of Robinia pseudoacacia}

\section{Cadmium}

Statistically significant differences in the concentrations of $\mathrm{Cd}$ were found in leaves and seeds (Table 2, numbers in rows). At the sites subsumed under the LR category the concentration of this metal in leaves was higher when compared to the sampling sites belonging to the other categories, although statistically significant differences were identified only between the LR and IL category. In the case of seeds, statistically significant differences occurred between the LR and IH categories. The least amount of Cd was found in leaves from the IL category as well as in seeds from the IH category. However, significant differences were only observed between the IH and IL for leaves, in which the Cd concentration in the IL category was substantially lower.

\section{Iron}

Statistically significant differences in the concentration of Fe between the categories were found for each $R$. pseudoacacia organ investigated (Table 2). The highest amount of Fe in leaves, seeds, shoots, and pericarps was observed in the samples of the RW category. On the other hand the lowest amount of $\mathrm{Fe}$ was found in shoots and pericarps of the LR category.

\section{Lead}

The highest concentration of $\mathrm{Pb}$ was found in the bark of trees belonging to the LR category, whereas the lowest was in the bark of trees from the RW category with differences being statistically significant (Table 2). Compared to the other categories a considerably higher concentration of $\mathrm{Pb}$ was also found in the pericarps from the LR category. The amount of $\mathrm{Pb}$ in the leaves, seeds, and shoots did not differ substantially among the categories.

\section{Copper}

The lowest concentration of $\mathrm{Cu}$ was observed in the bark of trees from the LR category, while in the bark of trees from the RW category the concentration of $\mathrm{Cu}$ was at its highest and the differences were statistically significant (Table 2). A similar tendency was observed in leaves. The highest amount of $\mathrm{Cu}$ in seeds was found in the LR category and the lowest in the IH category. No significant differences in the concentration of this metal were observed among the categories in shoots and pericarps.

\section{Zinc}

The highest amount of $\mathrm{Zn}$ was found in bark and shoots from the IH category (Table 2), while the highest concentration of $\mathrm{Zn}$ in pericarps was observed in the LR category. However, the amount of $\mathrm{Zn}$ from the latter category did not vary considerably from the amount in the IH category. No statistically significant differences of $\mathrm{Zn}$ concentrations in leaves and seeds were found among the categories.

The data provided above (Table 2) indicate that the sampling sites in the LR are more heavily contaminated with $\mathrm{Cd}$ and $\mathrm{Pb}$ when compared to the sampling sites from the other categories, including the IH category. On the other hand, the highest concentration of $\mathrm{Zn}$ in most of the organs of R. pseudoacacia can be found in the IH category. The highest amount of $\mathrm{Fe}$ and $\mathrm{Cu}$ occurred in the RW category, which can be attributed to the vicinity of railway tracks. Since one of the effects of abrasion of railway tracks and traction are metallic $\mathrm{Fe}$ and $\mathrm{Cu}$, it can be assumed that the accumulation of those forms of the elements occurs mainly in bark and leaves. Therefore, Fig. 2 shows the concentrations of $\mathrm{Fe}$ and $\mathrm{Cu}$ in the above-mentioned organs from the different sampling sites subsumed under the RW category. The highest amount of Fe $\left(1,208 \mathrm{mg} \mathrm{kg}^{-1}\right)$ in the bark of $R$. pseudoacacia was found at the sampling site in Tenczynek and Rudno (TR1), which is situated approximately $2 \mathrm{~m}$ below the tracks of a frequently used railway line. The lowest concentration of Fe (202 $\left.\mathrm{mg} \mathrm{kg}^{-1}\right)$ was detected in Sosnowiec (SO5), where the sampling site was located at the same level of a rarely used railway line leading to an industrial plant. Moderate concentrations were found in the bark of $R$. pseudoacacia at the sampling sites in Dąbrowa Górnicza and Będzin situated at the same level as the tracks of a frequented railway line. The concentration of $\mathrm{Fe}$ in leaves exhibited a tendency similar to the concentration of this element in bark. Nevertheless, such significant differences in the concentrations of $\mathrm{Fe}$ in leaves were not detected among the sampling sites as it was observed in bark. A similar concentration relationship to that of $\mathrm{Fe}$ was observed with $\mathrm{Cu}$ in the bark of $R$. pseudoacacia (Fig. 2).

\section{Comparison of Metal Concentrations in Different Plant Parts}

In order to evaluate the usefulness of particular organs for bioindication purposes, we compared mean metals' 

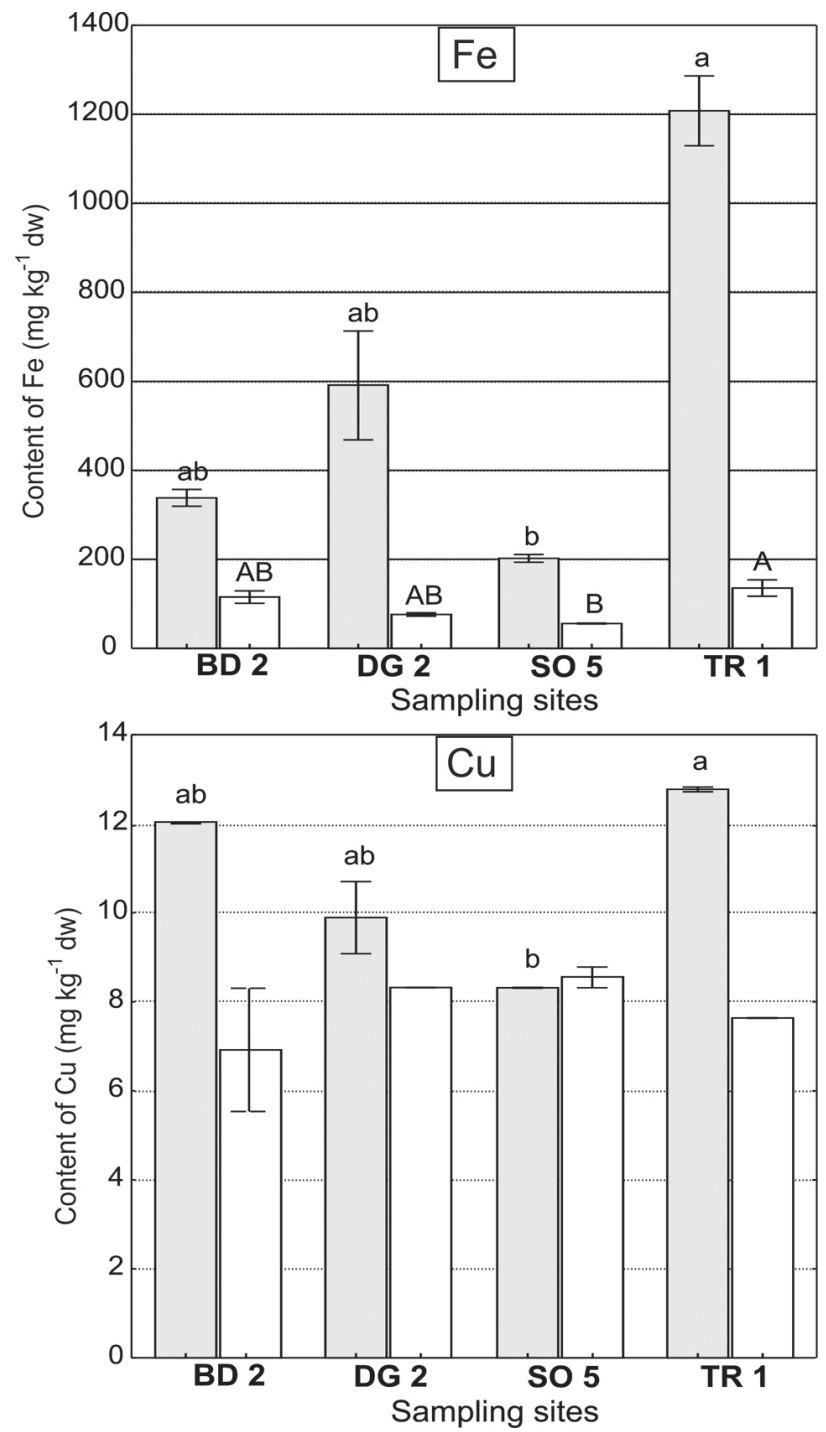

Fig. 2. Concentrations $\left(\mathrm{mg} \mathrm{kg}^{-1}\right)$ of $\mathrm{Fe}$ and $\mathrm{Cu}$ in bark (grey bars) and leaves (white bars) of Robinia pseudoacacia collected at the sampling sites situated in the vicinity of the railway tracks. Values are means \pm SE. Values followed by the same letter (a-b, for bark and A-B, for leaves) are not significantly different from each other using ANOVA and post hoc test LSD $(p<0.05)$. BD - Będzin, DG - Dąbrowa Górnicza, SO - Sosnowiec, TR - Tenczynek and Rudno.

concentrations in all organs for all categories (Fig. 3). The highest amounts of $\mathrm{Cd}, \mathrm{Pb}$, and $\mathrm{Fe}$ were found in bark, whereas the highest concentrations of $\mathrm{Cu}$ and $\mathrm{Zn}$ were observed in seeds. Apart from $\mathrm{Zn}$ in shoots and pericarp, no significant differences in the amount of the metals were detected (Fig. 3).

\section{Correlation between Element Concentrations in} Organs and Tissues of Robinia pseudoacacia

Table 3 shows Spearman's rank correlation coefficients between element concentrations in each organ and tissue as well as between various organs and tissues of $R$. pseudoacacia. The largest number of statistically significant corelations were found between bark and leaves,
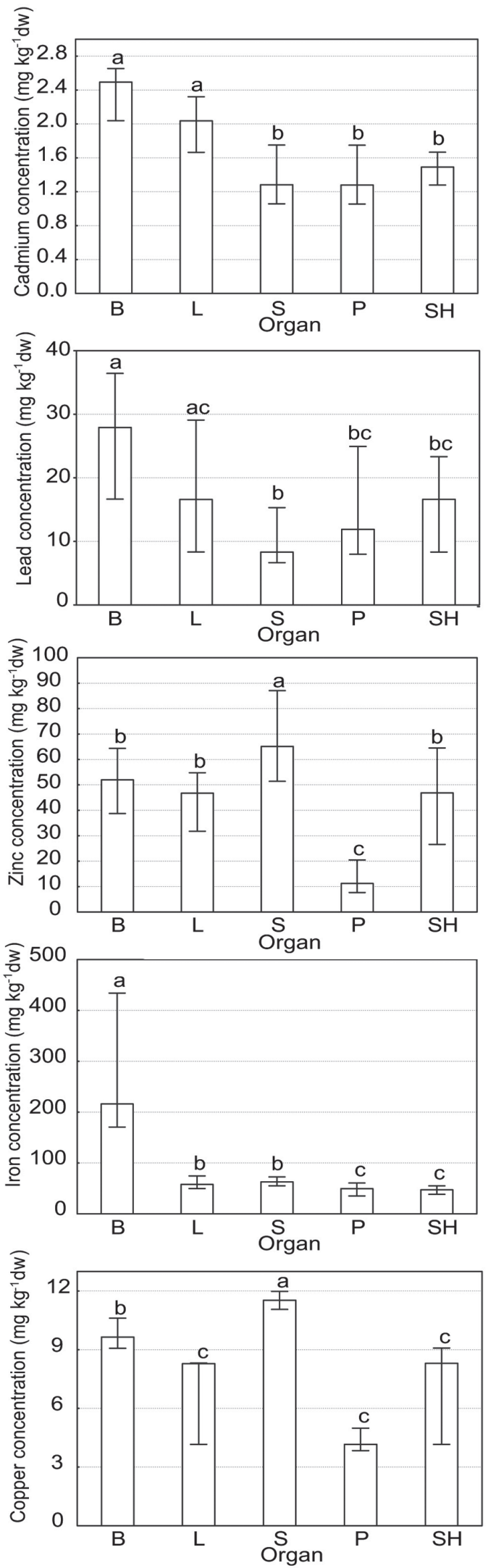

Fig. 3. Comparison of metal concentrations ( $\mathrm{mg} \mathrm{kg}^{-1}$ ) among Robinia pseudoacacia organs and tissues. Values are medians \pm quartiles $(n=49-57)$. Medians followed by the same letter are not significantly different from each other using the KruskalWallis non-parametric analysis of variance and post hoc multiple comparison test $(p<0.05)$. B - bark, $\mathrm{L}-$ leaves, $\mathrm{S}-$ seeds, $\mathrm{P}$ - pericarps, $\mathrm{SH}-$ young shoots. 


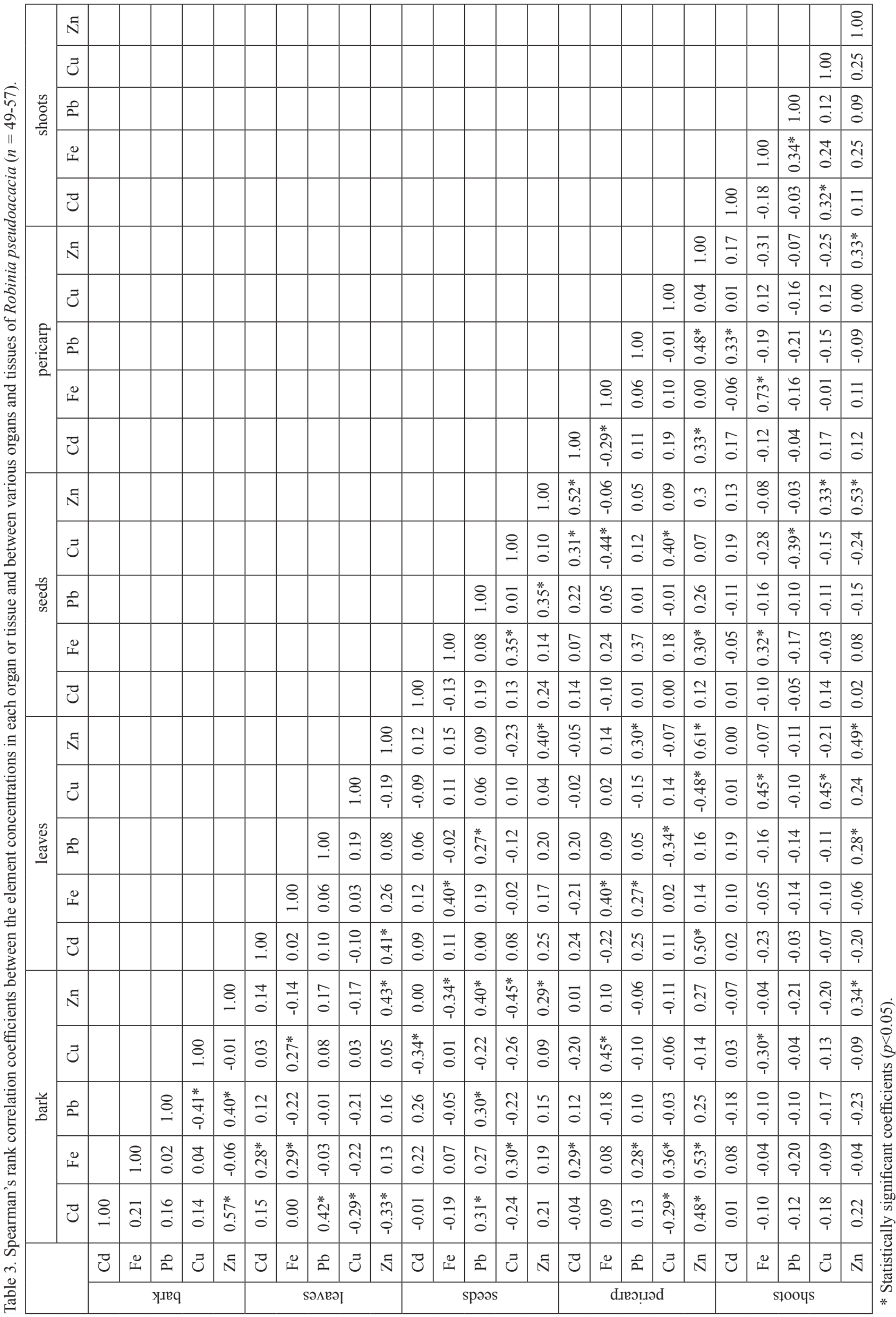




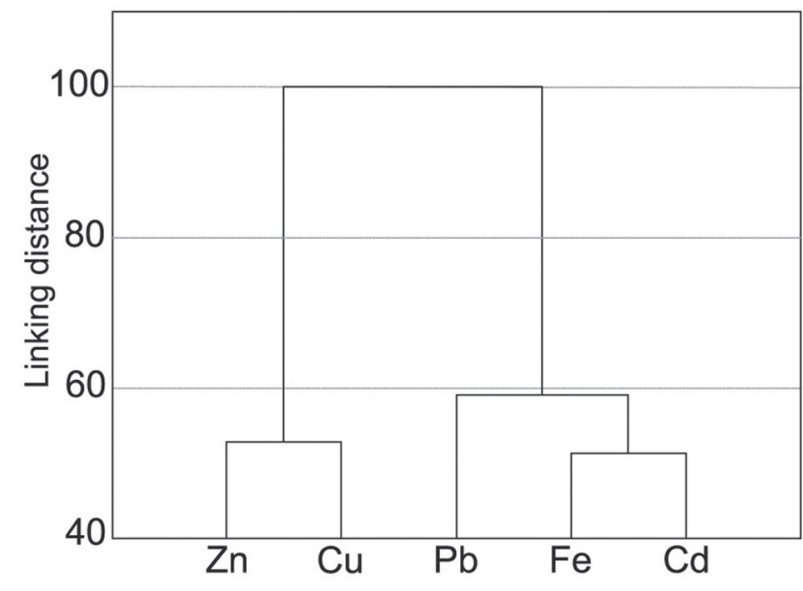

Fig. 4. Cluster analysis dendrogram concerning element concentrations in organs and tissues according to average linkage between the groups and Pearson's correlation as a measure of interval.

bark and seeds, bark and pericarp, leaves and pericarp, and seeds and pericarp. Although we found that the $\mathrm{Cd}$ concentration in $R$. pseudoacacia is positively correlated with the concentrations of $\mathrm{Zn}$ and $\mathrm{Pb}$, it is negatively correlated with the concentration of $\mathrm{Cu}$ apart from the positive interaction of $\mathrm{Cd}-\mathrm{Cu}$ in shoots. Predominantly positive correlations were observed between $\mathrm{Fe}$ and other elements. The $\mathrm{Pb}$ concentration was positively correlated with the $\mathrm{Zn}$ and $\mathrm{Cd}$ concentrations, but it was negatively correlated with the $\mathrm{Cu}$ concentration. The $\mathrm{Cu}$ concentration was negatively correlated with the $\mathrm{Cd}$, $\mathrm{Zn}$, and $\mathrm{Pb}$ concentrations. The amount of $\mathrm{Zn}$ correlated positively with the amount of $\mathrm{Cu}$ and $\mathrm{Cd}$, whereas it correlated negatively with the amount of $\mathrm{Fe}$ and $\mathrm{Cu}$.

A dendrogram showing similarities among concentrations of analyzed metals in organs and tissues is presented in Fig. 4. The cluster analysis revealed three clusters, of which one embraced the two microelements $\mathrm{Cu}$ and $\mathrm{Zn}$, the second $\mathrm{Pb}$, and the third $\mathrm{Cd}$ and $\mathrm{Fe}$.

\section{Comparison of Element Concentrations between Cities}

The highest concentration of Cd was found in Tenczynek and Rudno regardless of whether the concentration of this metal was analyzed in bark (Table 4A) or leaves (Table 4B). This high concentration of $\mathrm{Cd}$ in an area situated far from industrial plants can be attributed to longrange transport. The highest Fe concentrations in bark were detected in Tenczynek and Rudno (691.1 $\mathrm{mg} \mathrm{kg}^{-1}$ ), and they differed in a statistically significant manner from the concentrations in other examined areas (185.4$257.6 \mathrm{mg} \mathrm{kg}^{-1}$; Table 4A). The highest concentrations of $\mathrm{Cu}$ were observed in Będzin and Dąbrowa Górnicza, whereas the lowest concentrations were found in Tenczynek and Rudno (Table 4). The lowest concentrations of $\mathrm{Pb}$ and $\mathrm{Zn}$ were detected in Będzin, whereas no statistically significant differences in the concentrations of both elements were observed among the other examined areas.

\section{Discussion}

The results presented in this paper suggest that bark could be a very good bioindicator of air contamination with $\mathrm{Cd}, \mathrm{Pb}$, and $\mathrm{Fe}$, which correlates with the highest concentrations of these elements in bark when compared to other organs and tissues. The research conducted by Samecka-Cymerman et al. [32] in the town of Oleśnica (Poland), in which the main air contamination source is traffic, indicated that the concentrations of $\mathrm{Cd}, \mathrm{Pb}$, and $\mathrm{Fe}$ in the bark of R. pseudoacacia amounted to $0.8,58$, and $106 \mathrm{mg} \mathrm{kg}^{-1}$, respectively. Higher concentrations of $\mathrm{Cd}$ and $\mathrm{Fe}$ in the bark of $R$. pseudoacacia, which were

Table 4. Comparison of element concentrations between the cities in Robinia pseudoacacia organs and tissues, (A) in bark (B) in leaves.

\begin{tabular}{|c|c|c|c|c|c|c|}
\hline \multirow{2}{*}{$\begin{array}{c}\text { Sampling } \\
\text { area }\end{array}$} & Cd & Fe & Pb & Cu & $Z n$ \\
\cline { 2 - 7 } & \multicolumn{5}{|c|}{ (A) } \\
\hline BD & $2.01 \pm 0.10(2.04) \mathrm{b}$ & $253.6 \pm 34.05(257.6) \mathrm{b}$ & $19.3 \pm 2.53(16.6) \mathrm{b}$ & $10.7 \pm 0.43(9.65) \mathrm{a}$ & $36.6 \pm 3.77(41.5) \mathrm{b}$ \\
\hline $\mathrm{DG}$ & $2.34 \pm 0.10(2.50) \mathrm{ab}$ & $269.4 \pm 57.93(207) .6 \mathrm{~b}$ & $27.1 \pm 2.39(29.0) \mathrm{ab}$ & $9.38 \pm 0.42(9.65) \mathrm{ab}$ & $57.1 \pm 2.04(54.7) \mathrm{a}$ \\
\hline $\mathrm{SO}$ & $2.48 \pm 0.20(2.62) \mathrm{ab}$ & $183.9 \pm 6.44(185.4) \mathrm{b}$ & $35.2 .78(36.3) \mathrm{a}$ & $9.69 \pm 0.29(9.65) \mathrm{ab}$ & $60.7 \pm 6.84(64.4) \mathrm{a}$ \\
\hline TR & $2.60 \pm 0.11(2.50) \mathrm{a}$ & $752.1 \pm 104.1(691.1) \mathrm{a}$ & $27.4 \pm 4.43(34.8) \mathrm{ab}$ & $8.32 \pm 0.90(7.64) \mathrm{b}$ & $41.6 \pm 6.73(43.8) \mathrm{ab}$ \\
\hline \multicolumn{7}{|c|}{$(\mathbf{B})$} \\
\hline BD & $1.87 \pm 0.08(1.84) \mathrm{b}$ & $63.5 \pm 7.67(52.3)$ & $11.3 \pm 1.29(9.97) \mathrm{b}$ & $7.15 \pm 0.58(8.29) \mathrm{ab}$ & $29.4 \pm 2.91(24.9) \mathrm{b}$ \\
\hline DG & $1.93 \pm 0.13(2.20) \mathrm{ab}$ & $70.6 \pm 4.66(68.7)$ & $25.6 \pm 2.87(26.9) \mathrm{a}$ & $8.59 \pm 0.39(8.69) \mathrm{a}$ & $52.1 \pm 2.87(49.4) \mathrm{a}$ \\
\hline $\mathrm{SO}$ & $2.13 \pm 0.09(2.20) \mathrm{ab}$ & $61.2 \pm 4.30(54.9)$ & $23.4 \pm 3.24(20.7) \mathrm{a}$ & $5.86 \pm 0.56(4.16) \mathrm{bc}$ & $54.2 \pm 4.86(54.7) \mathrm{a}$ \\
\hline TR & $2.41 \pm 0.17(2.62) \mathrm{a}$ & $74.2 \pm 12.52(61.9)$ & $21.2 \pm 3.95(16.6) \mathrm{ab}$ & $4.69 \pm 0.55(3.85) \mathrm{c}$ & $49.8 \pm 4.26(43.4) \mathrm{a}$ \\
\hline
\end{tabular}

Values are means \pm SE. For (A) and (B) $n=12$. Numbers in brackets are medians. Medians followed by the same letter are not significantly different from each other using the Kruskal-Wallis non-parametric analysis of variance and post hoc multiple comparison test $(p<0.05)$. BD - Będzin, DG - Dąbrowa Górnicza, SO - Sosnowiec, TR - Tenczynek and Rudno. 
found in categories IH and IL, when compared to the results presented by Samecka-Cymerman et al. [32], indicate that industry is a vital factor when it comes to air contamination by these elements. The highest concentration of $\mathrm{Pb}$ in the bark of $R$. pseudoacacia was observed in plants growing in countryside areas (category LR) and did not vary significantly from the concentration of $\mathrm{Pb}$ in the bark in urban areas (categories IH and IL), in which $R$. pseudoacacia was exposed to industrial and traffic contamination. Similar concentrations of this metal in the bark of Fraxinus pensylvanica were found by Fujiwara et al. [47] in Buenos Aires as well as by Faggi et al. [69] in Montevideo, both in heavily trafficked areas. Slightly lower concentrations of $\mathrm{Pb}$ than those provided for both South American cities were observed by Samecka-Cymerman et al. [32] for R. pseudoacacia in the town of Oleśnica. Based on the data presented above, a conclusion can be drawn that in the case of categories $\mathrm{IH}$ and $\mathrm{IL}$ the $\mathrm{Pb}$ concentration in air comes from traffic and industry, on the other hand in category LR mainly from long-range transport of industrial emissions. These results suggest that $R$. pseudoacacia bark might be used for biomonitoring the long-range transport of industrial emissions.

Similar to bark, leaves seem to be good bioindicators of $\mathrm{Cd}$ and $\mathrm{Pb}$ as the accumulation of these elements is only slightly lower when compared to the accumulation found in bark. This correlation has been observed regardless of the category. Samecka-Cymerman et al. [32] obtained similar results and stated that the bark of $R$. pseudoacacia is a good bioindicator of long-term cumulative traffic pollution, whereas leaves are good indicators of short-term seasonal accumulation trends. The leaves of $R$. pseudoacacia were successfully used by other authors as well [39-40, 43, 49, 55, 59].

Data presented in this paper show significantly lower concentrations of $\mathrm{Cu}$ and $\mathrm{Zn}$ in bark and leaves when compared to seeds. In the seeds of broad bean (Vicia faba var major), the concentrations of $\mathrm{Cu}$ and $\mathrm{Zn}[70,71]$ were similar to the results presented in this paper. The above data suggest that both $\mathrm{Cd}$ and $\mathrm{Zn}$ as microelements, due to their physiological functions, are stored in seeds and that air contamination is not one of their sources. Therefore, the above results could suggest little potential for the use of seeds as an ecological indicator of air contamination with $\mathrm{Cu}$ and $\mathrm{Zn}$. This does not, however, exclude the possibility of applying other organs of $R$. pseudoacacia (bark and leaves in particular) in determining the level of air contamination with $\mathrm{Cu}$ and $\mathrm{Zn}$. The usefulness of the chestnut leaves for biomonitoring $\mathrm{Cu}$ in areas highly contaminated with these elements was demonstrated by Aničić et al. [42].

Data on the use of shoots for air biomonitoring is scarce, and we found only a few publications, including two concerning shoots of $R$. pseudoacacia $[59,60]$ and another one concerning the shoots of Populus alba [72]. In their research on the concentrations of $\mathrm{Cu}, \mathrm{Pb}$, and $\mathrm{Zn}$ in leaves and shoots of $R$. pseudoacacia, Serbula et al. [59] found higher concentrations of $\mathrm{Cu}$ and $\mathrm{Zn}$ in shoots than in leaves. Monfared et al. [60] also observed higher concentrations of $\mathrm{Cd}$ and $\mathrm{Pb}$ in shoots of $R$. pseudoacacia when compared to leaves. However, typically lower concentrations of $\mathrm{Cu}, \mathrm{Fe}, \mathrm{Pb}$, and $\mathrm{Zn}$ in shoots in comparison with the leaves of Populus alba were observed by Madejón et al. [72]. In this paper significantly lower concentrations in the shoots when compared to the leaves of $R$. pseudoacacia were found in the case of $\mathrm{Cd}$ and Fe. Taking into account the data presented above and the low number of articles on the use of shoots for biomonitoring, it remains to be seen whether this organ could be used for determining air contamination.

As pericarp had not been used for air biomonitoring until recently, an attempt has been made in this paper to test the usefulness of this tissue for determining the concentrations of metals in air. As is evident from the data presented in Table 2 and Fig. 3, no significant differences in the concentrations of the examined elements in pericarp were observed, the only exception being zinc. Thus although it is suggested that, like seeds and shoots, pericarp does not seem to be a good bioindicator, further investigations are needed.

Data on the concentrations of $\mathrm{Cd}, \mathrm{Cu}, \mathrm{Mn}, \mathrm{Ni}, \mathrm{Pb}$, and $\mathrm{Zn}$ in leaves and flowers of $R$. pseudoacacia suggest that flowers of $R$. pseudoacacia are better bioindicators of $\mathrm{Pb}$ and $\mathrm{Zn}$ when compared to leaves [58]. However, the concentrations of both metals in the flowers and leaves of $R$. pseudoacacia found by Gjorgieva et al. [58] are considerably higher than the concentrations of these metals observed by the authors of this paper in all the examined organs and tissues. Because of inconsistent results it seems that conducting further research in order to determine the usefulness of flowers of $R$. pseudoacacia as a bioindicator of metal contamination of air is necessary.

On the basis of the conducted research it was possible to determine the differences in contamination of the examined areas. The lowest concentrations of $\mathrm{Cd}, \mathrm{Pb}$, and $\mathrm{Zn}$ were found in Będzin (BD). Although the town is a part of the USIR, many industrial plants situated there have been closed since the 1990s. The results presented in this paper seem to show that $R$. pseudoacacia could be a good bioindicator of air contamination and made it possible to demonstrate improvement in Będzin air quality. On the other hand, in Tenczynek and Rudno, which are agricultural areas, the concentrations of $\mathrm{Cd}, \mathrm{Pb}$, and $\mathrm{Zn}$ were similar to those found in the cities with still functioning industry - Dąbrowa Górnicza and Sosnowiec - which can be linked to long-range transport of industrial emissions.

As a result of conducted cluster analysis, three groups of elements were distinguished. The first one consisted of $\mathrm{Zn}$ and $\mathrm{Cu}$, as these elements fulfill important physiological functions and are mainly accumulated in seeds. Copper and zinc are microelements and therefore it is tempting to suggest that they were predominantly taken up by roots and to a much lower extent absorbed from the air. The second cluster consists of $\mathrm{Pb}$, and the third cluster consists of Fe and $\mathrm{Cd}$. These two clusters are located on the one big branch of the dendrogram. The fact that both $\mathrm{Pb}$ and $\mathrm{Cd}$ (elements that have no physiological functions) are in 
the one big cluster could suggest that their accumulation in the organs and tissues of $R$. pseudoacacia was mainly connected with the absorption of these elements from the air. Also, a microelement (Fe) was found in the same cluster as the toxic element $\mathrm{Cd}$. This shows that it could come predominantly from the air and may be indicative of high concentrations of this element in the examined area, in particular in the vicinity of railway tracks.

\section{Conclusions}

The results presented in this paper and the data from references suggest that $R$. pseudoacacia may be a good bioindicator of metal contamination of air. Of the examined organs, bark and leaves appeared to be most useful for bioindication, while pericarp, seeds, and shoots appeared less effective. $R$. pseudoacacia might be used to examine the long-range transport of emissions, the effect of railway tracks, and the level of metal contamination of air in cities. However, more investigations in Europe and other parts of the world are necessary. Among the examined cities, Będzin was found to be the least contaminated area, which corresponds with the fact that many industrial plants in this city are out of operation. Interestingly, the villages Tenczynek and Rudno, which are agricultural areas, were found to be contaminated with metals to a similar extent as the cities, which is likely to be connected with the longrange transport of emissions.

\section{Acknowledgements}

The authors would like to thank Dr. Ewa Kurczyńska for valuable comments on our paper. We are also grateful to Agnieszka Małkowska for her contribution to linguistic corrections of the text.

\section{References}

1. KABATA-PENDIAS A., PENDIAS H. Trace elements in soils and plants, third ed. CRC Press LLC, 2000 N.W. Corporate Blvd., Boca Raton, Florida, USA, 2001.

2. CONTI M.E., PINO A., BOTRÈ F., BOCCA B., ALIMONTI A. Lichen Usnea barbata as biomonitor of airborne elements deposition in the Province of Tierra del Fuego (southern Patagonia, Argentina). Ecotoxicology and Environmental Safety 72, 1082, 2009

3. GRODZIŃSKA K.M., SZAREK-ŁUKASZEWSKA G. Response of mosses to the heavy metal deposition in Poland - an overview. Environmental Pollution 114, 443, 2001.

4. WOLTERBEEK B. Biomonitoring of trace element air pollution: principles, possibilities and perspectives. Environmental Pollution 120, 11, 2002V

5. ZHANG ZH.H., CHAI Z.F., MAO X.Y., CHEN J.B. Biomonitoring trace element atmospheric deposition using lichens in China. Environmental Pollution 120, 157, 2002.

6. SORBO S., APRILE G., STRUMIA S., CASTALDO COBIANCHI R., LEONE A., BASILE A. Trace element accumulation in Pseudevernia furfuracea (L.) Zopf exposed in Italy`s so called Triangle of Death. Science of The Total Environment 407, 647, 2008.

7. GODINHO R.M., VERBURG T.G., FREITAS M.C., WOLTERBEEK H.Th. Accumulation of trace elements in the peripheral and central parts of two species of epiphytic lichens transplanted to a polluted site in Portugal. Environmental Pollution 157, 102, 2009.

8. ŠAKALYS J., KVIETKUS K., SUCHAROVÁ J., SUCHARA I., VALIULIS D. Changes in total concentrations and assessed background concentrations of heavy metals in moss in Lithuania and the Czech Republic between 1995 and 2005. Chemosphere 76, 91, 2009.

9. MIGASZEWSKI Z.M., GAŁUSZKA A., DOŁĘGOWSKA S., CROCK, J.G., LAMOTHE P.J. Mercury in mosses Hylocomium splendens (Hedw.) B.S.G. and Pleurozium schreberi (Brid.) Mitt. from Poland and Alaska: Understanding the origin of pollution sources. Ecotoxicology and Environmental Safety 73, 1345, 2010.

10. KŁOS A., RAJFUR M., ŠRÁMEK I., WACŁAWEK M. Use of lichen and moss in assessment of forest contamination with heavy metals in Praded and Glacensis Euroregions (Poland and Czech Republic). Water, Air and Soil Pollution 222, 367-376. 2011.

11. BAČEVA K., STAFILOVA T., ŠAJN R., TĂNĂSELIA C. Air dispersion of heavy metals in the vicinity of the As-Sb-Tl abounded mine and responsiveness of moss as a biomonitoring media in small-scale investigations Environmental Science and Pollution Research 20, 8763, 2013.

12. VARELA Z., ROILOA S.R., FERNÁNDEZ J.A., RETUERTO R., CARBALLEIRA A., ABOAL J.R. Physiological and growth responses of transplants of the moss Pseudoscleropodium purum to atmospheric pollutants. Water, Air and Soil Pollution 224, 1753, 2013.

13. KAPUSTA P., SZAREK-ŁUKASZEWSKA G., GODZIK B. Present and past deposition of heavy metals in Poland as determined by moss monitoring. Polish Journal of Environmental Studies 23, 2047, 2014.

14. SHUKLA V., UPRETI D.K., BAJPAI R., YUNUS M. Spatial distribution of metallic content in Himalayan Ecosystem monitored using lichens. Water, Air and Soil Pollution 225, 1859, 2014.

15. AL-ALAWI M.M., MANDIWANA K.L. The use of Aleppo pine needles as a bio-monitor of heavy metals in the atmosphere. Journal of Hazardous Materials 148, 43, 2007.

16. GRATANI L., CRESCENTE M.F., VARONE L. Long-term monitoring of metal pollution by urban trees. Atmospheric Environment 42, 8273, 2008.

17. KAPUSTA P., SZAREK-ŁUKASZEWSKA G., GODZIK B. Spatio-temporal variation of element accumulation by Moehringia trinervia in a polluted forest ecosystem (South Poland). Environmental Pollution 143, 285, 2006.

18. DIVAN JUNIOR A.M., DE OLIVEIRA P.L., PERRY C.T., ATZ V.L., AZZARINI-ROSTIROLA L.N., RAYARODRIGUEZ M.T. Using wild plant species as indicators for the accumulation of emissions from a thermal power plant, Candiota, South Brazil. Ecological Indicators 9, 1156, 2009.

19. BONANNO G., LO GIUDICE R. Heavy metal bioaccumulation by the organs of Phragmites australis (common reed) and their potential use as contamination indicators. Ecological Indicators 10, 639, 2010.

20. UGULU I., DOGAN Y., BASLAR S., VAROL O. Biomonitoring of trace element accumulation in plants growing at Murata Mountain. International Journal of Environment Science and Technology 9, 527, 2012. 
21. BOROWIAK K., ZBIERSKA J., BARAŁKIEWICZ D., HANĆ A., BUDKA A., KAYZER D., KAWALA A. Biomonitoring of air pollution by trace elements using italian ryegrass (Lolium multiflorum L. 'Lema'). Polish Journal of Environmental Studies 23, 681, 2014.

22. JĘDRZEJCZYK M., ROSTAŃSKI A., MAŁKOWSKI E. Accumulation of zinc and lead in selected taxa of the genus Viola L. Acta Biologica Cracoviensia, series Botanica 44, 49, 2002.

23. GUCWA-PRZEPIÓRA E., MAŁKOWSKI E., SASNOWOSIELSKA A., KUCHARSKI R., KRZYŻAK J., KITA A., RÖMKENS P.F.A.M. Effect of chemophytostabilization practices on arbuscular mycorrhiza colonization of Deschampsia cespitosa ecotype Waryński at different soil depths. Environmental Pollution 150, 338, 2007.

24. JONSSON A., EKLUND M., HÅKANSSON K. Heavy metals of the $20^{\text {th }}$ century recorded in oak tree rings. Journal of Environmental Quality 26, 1638, 1997.

25. MORENO E., SAGNOTTI L., DINARÈS-TURELL J., WINKLER A., CASCELLA A. Biomonitoring of traffic air pollution in Rome using magnetic properties of tree leaves. Atmospheric Environment 37, 2967, 2003.

26. ROSSINI OLIVA S., MINGORANCE M.D. Assessment of airborn heavy metal pollution by aboveground plant parts. Chemosphere 65, 177, 2006.

27. QIU Y., GUAN D., SONG W., HUANG K. Capture of heavy metals and sulfur by foliar dust in urban Huzhou, Guangdong Provinece, China. Chemosphere 75, 447, 2009.

28. SETA-KOSELSKA A., SZCZUKA E., SKÓRZYŃSKAPOLIT E., DOMACIUK M., GIEŁWANOWSKA I. Roadside larch trees (Larix Mill.) and its female generative organs as a biomonitor of air pollution. Polish Journal of Environmental Studies 23, 867, 2014.

29. SEVIK A., CETIN M. Effect of water stress on seed germination for selected landscape plants. Polish Journal of Environmental Studies 24, 689, 2015.

30. SEVIK A., CETIN M., BELKAYALI N. Effects of forests on amounts of $\mathrm{CO}_{2}$ : case study of Castamonu and Ilgaz mountain national park. Polish Journal of Environmental Studies 24, 253, 2015.

31. PACHECO A.M.G., BARROS L.I.C., FREITAS M.C., REIS M.A., HIPÓLITO C., OLIVEIRA O.R. An evaluation of olive-tree bark for the biological monitoring of airborne trace-elements at ground level. Environmental Pollution 120, 79, 2002.

32. SAMECKA-CYMERMAN A., STANKIEWICZ A., KOLON K., KEMPERS A.J. Self-organizing feature map (neural networks) as a tool to select the best indicator of road traffic pollution (soil, leaves or bark of Robinia pseudoacacia L.). Environmental Pollution 157, 2061, 2009.

33. LEHNDORFF E., SCHWARK L. Biomonitoring od air quality in the Cologne Conurbation using pine needles as a passive sampler - Part III: major and trace elements. Atmospheric Environment 44, 28222010.

34. DMUCHOWSKI W., BYTNEROWICZ A. Monitoring environmental pollution in Poland by chemical analysis of scots pine (Pinus sylvestris L.) needles. Environmental Pollution 87, 87, 1995.

35. KURCZYŃSKA E.U., DMUCHOWSKI W., WŁOCH W., BYTNEROWICZ A. The influence of air pollutants on needles and stems of scots pine (Pinus silvestris L.) trees. Environmental Pollution 98, 325, 1997.

36. SAMECKA-CYMERMAN A., KOSIOR G., KEMPERS A.J. Comparison of the moss Pleurozium schreberi with needles and bark of Pinus sylvestris as biomonitors of pollution by industry in Stalowa Wola (southeast Poland). Ecotoxicology and Environmental Safety 65, 108, 2006.

37. TEPER E. Dust-particle migration around flotation tailings ponds: pine needles as passive samplers. Environmental Monitoring and Assessment 154, 383, 2009.

38. MARKO-WORŁOWSKA M., CHRZAN A., ŁACIAK T. Scots pine bark, topsoil and pedofauna as indicators of transport pollutions in terrestrial ecosystems. Journal of Environmental Science and Health 46, 138, 2011.

39. CICEK A., KOPARAL A.S. Accumulation of sulfur and heavy metals in soil and tree leaves sampled from the surroundings of Tunçbilek Thermal Power Plant. Chemosphere 57, 1031, 2004.

40. BAYCU G., TOLUNAY D., ÖZDEN H., GÜNEBAKAN S. Ecophysiological and seasonal variations in $\mathrm{Cd}, \mathrm{Pb}, \mathrm{Zn}$, and $\mathrm{Ni}$ concentrations in the leaves of urban deciduous trees in Istanbul. Environmental Pollution 143, 545, 2006.

41. TOMAŠEVIĆ M., VUKMIROVIĆ Z., RAJŠIĆ S., TASIĆ M., STEVANOVIĆ B. Contribution to biomonitoring of some trace metals by deciduous tree leaves in urban areas. Environmental Monitoring and Assessment 137, 393, 2008.

42. ANIČIĆ M., SPASIĆ T., TOMAŠEVIĆ M., RAJŠIĆ S., TASIĆ, M. Trace elements accumulation and temporal trends in leaves of urban deciduous trees (Aesculus hippocastanum and Tilia spp.). Ecological Indicators 11, 824, 2011.

43. SAWIDIS T., CHETTRI M.K., PAPAIOANNOU A., ZACHARIADIS G., STRATIS J. A study of metal distribution from lignite fuels using trees as biological monitors. Ecotoxicology and Environmental Safety 48, 27, 2001.

44. PUGH R.E., DICK D.G., FREDEEN A.L. Heavy metal (Pb, $\mathrm{Zn}, \mathrm{Cd}, \mathrm{Fe}$, and $\mathrm{Cu}$ ) contents of plant foliage near the Anvil Range lead/zinc mine, Faro, Yukon Territory. Ecotoxicology and Environmental Safety 52, 273, 2002.

45. WUYTACK T., VERHEYEN K., WUYTS K., KARDEL F., ADRIAENSSENS S., SAMSON R. The potential of biomonitoring of air quality using leaf characteristics of white willow (Salix alba L.). Environmental Monitoring and Assessment 171, 197, 2010.

46. CATINON M., AYRAULT S., BOUDOUMA O., ASTA J., TISSUT M., RAVANEL P. The inclusion of atmospheric particles into the bark suber of ash trees. Chemosphere 77, 1313, 2009.

47. FUJIWARA F.G., GÓMEZ D.R., DAWIDOWSKI L., PERELMAN P., FAGGI A. Metals associated with airborne particulate matter in road dust and tree bark collected in a megacity (Buenos Aires, Argentina). Ecological Indicators 11, 240, 2011.

48. MCALISTER R.H. Robinia pseudoacacia. U.S. Department of Agriculture, Forest Service, pp.1-6, 1971.

49. AKSOY A., SAHIN U., DUMAN F. Robinia pseudo-acacia L. as a possible biomonitor of heavy metal pollution in Kayseri. Turkish Journal of Botany 24, 279, 2000.

50. WEBER E. Invasive plant species of the world: a reference guide to environmental weeds. Wallingford: CABI Publishing pp. 548. 2003.

51. VON HOLLE B., JOSEPH K.A., LARGAY E.F., LOHNES R.G. Facilitations between the introduced nitrogen-fixing tree, Robinia pseudoaccacia, and nonnative plant species in the glacial outwash upland ecosystem of Cape Cod, MA. Biodiversity and Conservation 15, 2197, 2006.

52. VLACHODIMOS K., PAPATHEODOROU E.M., DIAMANTOPOULOS J., MONOKROUSOS N. Assessment of Robinia pseudoacacia cultivations as a restoration 
strategy for reclaimed mine spoil heaps. Environmental Monitoring and Assessment, 185, 6921, 2013.

53. ZELEZNIK J.D., SKOUSEN J.G. Survival of three tree species on old reclaimed surface mines in Ohio. Journal of Environmental Quality 25, 1429, 1996.

54. MERTENS J., VERVAEKE P., DE SCHRIJVER A., LUYSSAERT S. Metal uptake by young trees from dredge brackish sediment: limitations and possibilities for phytoextraction and phytostabilisation. Science of The Total Environment 326, 209, 2004.

55. ÇELIK A., KARTAL A.A., AKDOĞAN A., KASKA Y. Determining the heavy metal pollution in Denizli (Turkey) by using Robinia pseudo-acacia L. Environment International 31, 105, 2005.

56. KAYA G., OKUMUS N., YAMAN M. Lead, cadmium and copper concentrations in leaves of Nerium oleander and Robinia pseudoacacia as biomonitors of amtospheric pollution. Fresenius Environmental Bulletin 19, 669, 2010.

57. VURAL A. Assessment of heavy metal accumulation in the roadside soil and plants of Robinia pseudoacacia, in Gümüşhane, Northeastern Turkey. Ekoloji 22, 1, 2013.

58. GJORGIEVA D., KADIFKOVA-PANOVSKA T., BAČEVA K., STAFILOVA T. Assessment of heavy metal pollution in Republica of Macedonia using a plant assay. Archives of Environmental Contamination and Toxicology 60, 233, 2011.

59. SERBULA S.M., MILJKOVIC D.DJ., KOVACEVIC R.M., ILIC A.A. Assessment of airborn heavy metal pollution using plant and topsoil. Ecotoxicology and Environmental Safety 76, 209, 2012.

60. MONFARED S.H., MATINIZADEH M., SHIRVANY A., AMIRI G.Z., FARD R.M., ROSTAMI F. Accumulation of heavy metals in Platanus orientalis, Robinia pseudoacacia and Fraxinus rotundifolia. Journal of Forestry Research 24, 391, 2013.

61. FERRANDON M., CHAMEL A.R. Cuticular retention, foliar absorption and translocation of $\mathrm{Fe}, \mathrm{Mn}$ and $\mathrm{Zn}$ supplied in organic and inorganic form. Journal of Plant Nutrition 11, 247, 1988.

62. MENGEL K., KIRKBY E.A., KOSEGARTEN H., APPEL T. Principles of plant nutrition, fifth ed. Kluwer Academic Publishers, Dordrecht, The Netherlands 2001.
63. CAKMAK I., WELCH R.M., HART J., NORVELL W.A., OZTÜRK L., KOCHIAN L.V. Uptake and retranslocation of leaf-applied cadmium $\left({ }^{109} \mathrm{Cd}\right)$ in diploid, tetraploid and hexaploid wheats. Journal of Experimental Botany 51, 221, 2000.

64. GREGER M., JOHANSSON M., STIHL A., HAMZA K. Foliar uptake of Cd by pea (Pisum sativum) and sugar beet (Beta vulgaris). Physiologia Plantarum 88, 563, 1993.

65. ROSS S.M. Toxic metals: fate and distribution in contaminated ecosystems. In S.M. Ross (Ed.), Toxic metals in soil-plant systems. John Wiley Sons Ltd., Chichester, England 189, 1994.

66. GRODZIŃSKA K., FRONTASYEVA M., SZAREKŁUKASZEWSKA G., KLICH, M., KUCHARSKA-FABIŚ A., GUNDORINA S.F., OSTROVNAYA T.M. Trace element contamination in industrial regions of Poland studied by moss monitoring. Environmental Monitoring and Assessment 87, 255, 2003.

67. OSTROWSKA A., GAWLIŃSKI S., SZCZUBIAŁKA Z. Metody analizy i oceny właściwości gleb i roślin. Katalog. Instytut Ochrony Środowiska. Warszawa. 1991.

68. ALAGIĆ S.Č., TOŠIĆ S.B., DIMITRIJEVIĆ M.D., ANTONIJEVIĆ M.M., NUJKIĆ M.M. Assessment of the quality of polluted areas based on the content of heavy metals in different organs of the grapevine (Vitis vinifera) $\mathrm{cv}$ Tamjanika. Environmental Science and Pollution Research, 22, 7155, 2015.

69. FAGGI A.M., FUJIWARA F., ANIOD C., PERELMAN P.E. Use of tree bark for comparing environmental pollution in different sites from Buenos Aires and Montevideo. Environmental Monitoring and Assessment 178, 237, 2011.

70. LISIEWSKA Z., KMIECIK W., GĘBCZYŃSKI P. Effect of maturity stages on the content of ash components in raw, frozen and canned broad beans. Food Chemistry 67, 155, 1999.

71. KMIECIK W., LISIEWSKA Z., JAWORSKA G. Content of ash components in the fresh and preserved broad bean (Vicia faba var. major). Journal of Food Composition and Analysis 13, 905, 2000.

72. MADEJÓN P., MARAÑÓN T., MURILLO J.M., ROBINSON B. White poplar (Populus alba) as a biomonitor of trace elements in contaminated riparian forests. Environmental Pollution 132, 145, 2004. 